\title{
Supply Chain Collaboration: A Triadic View
}

\author{
L. Huang ${ }^{1}$, Y. Lin, L. Zhou, Petros, Ieromonachou \\ ${ }^{1}$ Business School, University of Greenwich, London, United Kingdom \\ (e-mail address: L.Huang@gre.ac.uk)
}

\begin{abstract}
This research aims to investigate the collaboration patterns in supply chain with a triadic view. Case study was adopted in this research. Four triadic collaboration patterns throughout the whole supply chain have been summarized in according to various business segments. In upstream supply chain, there are two types of triadic collaboration pattern directed collaboration triad and cultivated collaboration triad; and in downstream supply chain, there are another two types of triadic collaboration patterns as well - concerted collaboration triad and derived collaboration triad.
\end{abstract}

Keywords - Collaboration, supply chain, triad, dyad

\section{INTRODUCTION}

The rise in outsourcing has led to a supply landscape increasingly relied on networks rather than traditional vertical-integrated firms. In order to achieve efficiency, flexibility, and competitive advantage [1], firms are increasingly developing collaborative relationships with their partners in the supply chain. Past researches in supply chain management (SCM) have focused on dyadic relationships (eg., supplier-buyer, supplier-customer) [2]. Unfortunately, this does not reflect the complex nature of a supply network. In fact, within the supply network, collaborations happened not only between supplier and manufacturer, but also between supplier and supplier, which is also called 'horizontal supply chain relationships' [3]. For example, there is a growing trend of suppliers collaborating with each other, not just competing with each other, to meet manufacturer's on-time delivery requirement $[4,5]$.

This forms a triadic structure of supplier-suppliermanufacturer, which is fundamental block of a supply network, and is critically important to supply chain performance. Such triad is fundamentally different from the dyad in the linear supply chains often studied in Operations Management (OM) and SCM for last few decades. With a triad view, it offers an opportunity to fully address supply chain collaboration in a broader threedimensional relationship context rather than a linear twodimensional context. For example, a triad view offers a way to study how a dyad is affected by another dyad in a supply network that is not studied in the past dyadic context [6]. Obviously, a triad view will help us to better understand the complex relationship in the supply network, and it will also move SCM research forward.
However, the research on the supply chain collaboration with a triadic view is still scarce. This paper will investigate the supply chain collaboration with a triad view. The main research objective is to explore the configuration patterns of triad in a supply network.

\section{METHODOLOGY}

This research adopted case study as research method. In the beginning of the research, a literature review is suggested to be generated to identify potential research questions. To uncover the operability of designed research construct, a pilot study is conducted to redefine the plan of data collection [7] which is confirmatory focus. And the results have contributed to the final decisions related to target industry and case criteria. To ensure the reliability [8] of the research in case studies, a research protocol has been designed to guide for data collection and applied as an interview tool for the semi-structured interviews. All the case companies are well-developed in recent years, and have certain market recognition. Brief overview of the participants is listed in TABLE I.

Table I

Participants of case study

\begin{tabular}{|c|c|}
\hline Case Company & Position of interviewee \\
\hline $\begin{array}{l}\text { AK pharmaceutical (CC-1) } \\
\text { (manufacturer, buyer, seller) }\end{array}$ & $\begin{array}{l}\text { President (1 Hour) } \\
\text { General manager ( } 3 \text { Hours, } 3 \text { times) } \\
\text { Manufacturer manager ( } 1.5 \text { Hours, } \\
\text { twice) }\end{array}$ \\
\hline $\begin{array}{l}\text { LF Pharmaceutical (CC-2) } \\
\text { (manufacturer, buyer, seller) }\end{array}$ & $\begin{array}{l}\text { Manufacturing manager ( } 2 \text { Hours, } \\
\text { twice) } \\
\text { Distribution manager ( } 5 \text { Hours, } 6 \\
\text { times) } \\
\text { R\&D Director (2 Hours, twice) } \\
\end{array}$ \\
\hline $\begin{array}{l}\text { HY Pharmaceutical (CC-3) } \\
\text { (manufacturer, buyer, seller) }\end{array}$ & $\begin{array}{l}\text { President (2.5 Hours, twice) } \\
\text { R\&D director ( } 3 \text { Hours, } 3 \text { times })\end{array}$ \\
\hline $\begin{array}{l}\text { TL Pharmaceutical (CC-4) } \\
\text { (manufacturer, buyer, seller) }\end{array}$ & $\begin{array}{l}\text { General manager ( } 1.5 \text { Hours, once) } \\
\text { Marketing manager ( } 2.5 \text { Hours, } 3 \\
\text { times) } \\
\text { Manufacturing manager ( } 1.5 \text { Hours, } \\
\text { once) }\end{array}$ \\
\hline $\begin{array}{l}\text { SY Pharmaceutical (CC-5) } \\
\text { (manufacturer, buyer, seller) }\end{array}$ & $\begin{array}{l}\text { President ( } 3.5 \text { Hours, } 3 \text { times) } \\
\text { R\&D director ( } 1.5 \text { Hours, twice) }\end{array}$ \\
\hline R\&D Institutions & Position of interviewee \\
\hline University A & $\begin{array}{l}\text { Leader of Pharmacy Department } \\
\text { ( } 2 \text { Hours, once) } \\
\text { Professor in Pharmacy Department } \\
\text { (1.5 Hours, once) }\end{array}$ \\
\hline University B & $\begin{array}{l}\text { Leader of Pharmacy Department } \\
(2.5 \text { Hours, once) }\end{array}$ \\
\hline $\begin{array}{c}\text { Pharmaceutical Material } \\
\text { Supplier }\end{array}$ & Position of interviewee \\
\hline
\end{tabular}




\begin{tabular}{|l|l|}
\hline $\begin{array}{l}\text { JN Pharmaceutical } \\
\text { (manufacturer, buyer, seller) }\end{array}$ & $\begin{array}{l}\text { CEO (1 Hour, once) } \\
\text { General Manager (1 Hour, once) }\end{array}$ \\
\hline $\begin{array}{l}\text { FY Pharmaceutical } \\
\text { (manufacturer, buyer, seller) }\end{array}$ & General Manager (1 Hour, once) \\
\hline $\begin{array}{l}\text { TS Pharmaceutical } \\
\text { (manufacturer, buyer, seller) }\end{array}$ & General Manager (1 Hour, once) \\
\hline \multicolumn{1}{|c|}{ Agency Company } & \multicolumn{1}{|c|}{ Position of interviewee } \\
\hline $\begin{array}{l}\text { MDX - (buyer, seller, service } \\
\text { provider) }\end{array}$ & $\begin{array}{l}\text { Marketing Executive (2.5 Hours, } \\
\text { twice) } \\
\text { Regional sales representative (1 } \\
\text { Hour, once) }\end{array}$ \\
\hline $\begin{array}{l}\text { LF - (buyer, seller, service } \\
\text { provider) }\end{array}$ & $\begin{array}{l}\text { Regional sales representative (2.5 } \\
\text { Hours, twice) }\end{array}$ \\
\hline $\begin{array}{l}\text { HY - (buyer, seller, service } \\
\text { provider) }\end{array}$ & $\begin{array}{l}\text { Regional sales representative (1 } \\
\text { Hour, once) }\end{array}$ \\
\hline 3PL & \begin{tabular}{l}
$|c|$ \\
Positon of interviewee \\
\hline DB
\end{tabular} \\
\hline YZSD & Maniness Manager (40 minutes, \\
\hline ZX & Business Manager (1 Hour, once) \\
\hline
\end{tabular}

For data analysis, techniques will be applied in this research are pattern matching, explanation building, logic models, and cross-case synthesis.

\section{RESULTS}

\section{A. Triadic collaboration configuration}

The results highlighted two basic triadic collaboration configurations in upstream and downstream supply chain (Fig. 1. and Fig. 2.).

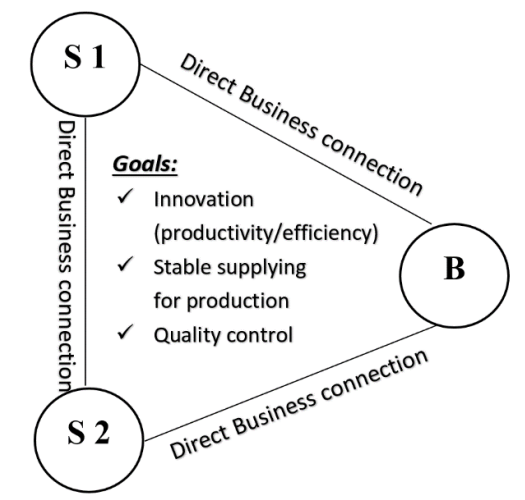

Fig. 1. Basic triadic collaboration configuration in upstream supply chain

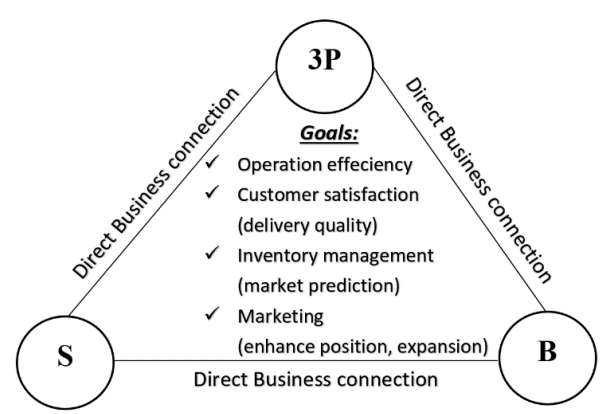

Fig. 2. Basic triadic collaboration configuration in downstream supply chain
When the focal company take the position of the buyer, in upstream of the supply chain, the triadic collaborative configuration can be constructed with their suppliers to progress innovation activities or ensure sustained production in the processes of R\&D and procurement.

When the focal company take the position of the supplier, in downstream of the supply chain, the triadic collaborative configuration is usually created with the involvement of Third Party (3P) in distribution and logistics which helps to satisfy customers' requirements and to better complete the business.

With these collaborative modes, this research identified several patterns build on the closeness of business connection in each modes. Here the closeness of the business connection refers to the degree of collaboration.

\section{B. Triadic collaboration patterns in upstream supply chain}

In upstream, suppliers involved in triadic collaboration seldom to collaborate in business relations with each other voluntarily without the integration initiated by the focal company; Supplier-supplier are in the relationship of "no tie" or "competitiveness" in certain area [9], where there is no direct business connection. The integration can be organized by the focal company when there is project to launch or there is a strong motivation of the focal company to achieve certain goals which requires assistance from other parties. The research data indicated that, usually, to ensure the power in integration is the premise for the focal companies to expand their networking. And there must be at least one tie of supplier-buyer in comparatively high degree collaboration, the triadic collaborative modes are possible to be formed.

Based on these, two triadic collaboration patterns can be summarized by the research - Directed Collaboration Triad and Cultivated Collaboration Triad in the upstream supply chain. And the details can be referred to the following illustrations.

Directed Collaboration Triad. In directed collaboration triads, as suppliers of the focal company, one of them collaborates with the buyer in a high level; while the another one with the buyer is in low collaboration. The triad is motivated based on the stable relationship between supplier 1 and the buyer; and the supplier 2 is involved to assist certain projects which are jointly worked by the buyer and supplier 1 .

In this case study, some of the pharmaceutical companies (peers of the focal company) are also regarded as business partners (suppliers) in the perspective of service/technology/patent providing. It is an important channel for the focal company to obtain professional assistance in both innovation and marketing. However, the collaboration is usually in a regular business behavior, which means certain R\&D achievements are traded as commodities; the supplier and buyer do not really have to co-research and develop on any project. Their relationship is restricted to basic business connection and knowledge/technology-transfer, where the collaboration is in a low level. 
Most of the time, the formation of a triad is motivated by a project; and in the project, usually, there are more than two parties including the focal company. The projects can be launched by universities or scientific research institutions which may sponsored by government; to respond to the policy of academic-industry collaboration, the focal company and the research parties are in high collaborations. Sometimes, due to shortage of equipment or other limit in qualification, a third party may be invited to make up. In this situation, no matter whom may played the role of the third party, the relationship between the new service/technology supplier and the focal company or the existing project partner is in basic business connection; which means the third party only have to do the work given by the dyadic alliance, and do not need to know much other information only when be informed. And this triadic collaboration is in this pattern.

Cultivated Collaboration Triad. In cultivated collaboration triads, both of the involved suppliers collaborate with the focal company in a high level; even without any mutual task/project, the dyadic relationships of the supplier-buyer are well maintained. Such triad can be constructed when the two suppliers are essential in completing a project, and it is necessary for the two parties communicate to approach certain goals.

The higher degree of collaboration between supplier 1 and supplier 2 allowed by the focal company in the project, the more stable and efficient of the triad can be expected. Generally saying, the supplier 1 or supplier 2 do not really need to connect with each other directly, as the focal company can be the messenger to exchange information relevant to any project. However, integrating the triad enables stakeholders to share information or resources in maximum and then further speed up issue processing in particular segment.

The cultivated triads are common in this case study. In the perspective of the focal company, based on existed highly collaborated dyads upstream; when two of them are involved into one project, it is worthy of consideration to bring them together for further collaborating.

In directed collaboration pattern, it has been introduced that SRI, University, and Hospital are parties have been regarded as very important partners to provide professional service or technologies. Driven by the polity of academicindustry collaboration, more and more projects have been launched to encourage innovations and thus to further promote the development in science and industry.

In this research, most of the involved cases are $R \& D$ oriented; teams formed by experts and young talents in relevant area are their potent force to compete in the market. The attitudes of held by the focal company to academic and research institutions are more alike "reliers" rather than "budies". When there are good projects, they are more confident about working with universities or research institutions if they are qualified in particular service providing or technical assistance; in the consideration of creditworthiness, professional levels, sustainability, and value added.
When there is a project launched by the focal company or the focal company is in a crucial position in any project, they can decide to involve another party when needed. If another party is selected from their "reliers", the triadic collaboration formed is in cultivated pattern. And in this pattern, the supplier-supplier relationships are dynamically changed refer to the nature of the project (government sponsored or Co-R\&D project or enterprise behavior), the willingness of the suppliers to collaborate, and the focal company's considerations (the reason to involve third party - technology/facility support or idea support or strategic disposition).

In government sponsored project, the $R \& D$ achievements usually have to be reported in details including the knowledge and application. Once three parties including the focal company have been involved, high degree collaborations can be built among the participants. University and research institution are quite similar in providing service/technology to focal company. In ordinary circumstances (Co-R\&D project or enterprise behavior), it is unusual to get them together in one project. However, in some large government sponsored project, it is possible; especially in the academic-industry collaboration projects.

\section{Triadic collaboration patterns in downstream supply chain}

In downstream supply chain, the third party involved by outsourcing the function of distribution and logistics is the main element to construct triadic network.

In downstream collaboration, the focal company as the supplier to provide pharmaceutical products are connected to relevant customers in different levels. Depend on the roles played by third party in network $[10,11]$, the attentions given to ties of $\mathrm{CC}-3 \mathrm{P}$ and $3 \mathrm{P}$-Customer are distinct. If the business connection is in a strategic perspective, where the performance of $3 \mathrm{P}$ could directly impact on not only customer satisfaction but also aspects of marketing, the CC-3P collaborations tend to be maintained by the focal company in a high level; and due to the 3P's strategic position, the 3P-Customer relationship is able to be built up in a high level also, sometimes even can be supported by the focal company. If the involvement of $3 \mathrm{P}$ is only to give assistance of distribution or logistics in operational level only, the level of CC-3P collaboration is usually depends on the trust for $3 \mathrm{P}$ of the focal company and the willingness to collaborate of $3 \mathrm{P}$ to the focal company; the 3P-Customer collaboration is less considered, which is to complete certain task only in a basic business connection.

Based on the results, another two triadic collaboration patterns can be summarized - Concerted Collaboration Triad and Derived Collaboration Triad in the downstream supply chain.

Concerted Collaboration Triad. In concerted collaboration triads, the focal company (supplier) and customer are in high degree collaboration; fixed purchasing contract may have signed between the two parties, regular communications about products or relevant 
feedback are usually available when required. The third party involved in the triads are usually the ones highly trusted by the focal company; which may represent the focal company to explain the business or deliver relevant services to customer. It is significant to ensure decision synchronization in mutual tasks, and the business incentives are correlated in a certain degree.

In downstream supply chain, the core issues are about distribution and logistics. In pharmaceutical industry, quality inspection is always important and draw attentions by the focal company in every stage. Regulations of GMP and GSP put forward many requirements to pharmaceutical companies in their procurement, $\mathrm{R} \& \mathrm{D}$, production, storage, sales, and logistics and so on. Due to the particularity of the products, sales personnel in this industry should have relevant practicing qualifications. Prescription medicines and OTC medicines can only be sold by qualified professional institutions and usually should equipped with medical guidance. There are many barriers of market-entry to the focal company, and they have to build good relationships ("guanxi") [12] in both individual level and organizational level; it takes time and costs much. Moreover, pharmaceutical product is different from other daily necessaries or foodstuffs; it requires comparatively very high quality in logistics service. For some bio-pharmaceuticals which are sensitive to temperature and humidity, special concerns have to be made. All these issues may motivate the focal companies to find the way out from outsource, and trusted third parted have advantages in professional areas are invited to help for better performance in distribution and logistics.

Derived Collaboration Triad. In derived collaboration triads, in the perspective of the focal company, the third party is involved as a regular service provider in a common business connection. The third party as a service provider is usually invited by the focal company; and the tasks given to the third party are normally a derived non-core business from an overall perspective. In this collaboration, only information relevant to the derived business will be shared; the path way (supplier-third party-customer) derived from the mainline (supplier-customer) is in charge of different but relevant works which may add value to the focal company's current business. The relationship between the focal company and the customer in mainline does not really impact on collaborations in the derived business.

The involvement of 3PLs can bring about benefits to the focal company like cost-saving and operation efficiency. Case companies do not deny that the 3PL plays an important role in their business, and most of informed that more than $90 \%$ of the delivery has been outsourced to 3PLs. Their 3PL partners could be any qualified company, and there is no particular preference. The collaborations of the focal companies with 3PLs are in low level compare to other strategic partners. The benefits of collaborations to the focal company can be reflected in pricing and priority of services provided; and to the 3PLs, certain amount of traffic can be guaranteed in a period overview. The focal company and 3PLs do not co-work for delivery, the focal company make the plan and then arrange and distribute the order to collaborated 3PLs; the 3PLs have to work in according to contracts, and are not able to interfere any decision making by the focal company. And that is why the relationship of the focal company and the customers will not impact on their collaborations with 3PLs; when there is order need to be delivered, the collaborated 3PLs are in fist select to do the job.

The relationship of 3PL and consignee (the customer) is in a regular business connection. Although some of the 3PLs indicate that when they believe the consignee could be a potential customer, they will try to keep the connection with them; the collaboration they may try to build is only in their professional area about logistics.

\section{CONCLUSION}

This research aims to investigate the collaboration patterns, and four triadic collaboration pattern throughout the whole supply chain has been summarized in according to various business segments. In upstream supply chain, there are two types of triadic collaboration pattern Directed Collaboration Triad and Cultivated Collaboration Triad; and in downstream supply chain, there are two types of triadic collaboration patterns as well - Concerted Collaboration Triad and Derived Collaboration Triad.

Future research will explore how there four collaboration triads work in the supply chain. More industries will be selected for case study to compare the difference in different industry contexts.

\section{REFERENCES}

[1] D. J. Beebe, "Signal conversion (Book style with paper title and editor)," in Biomedical Digital Signal Processing, W. J. Tompkins, Ed. Englewood Cliffs, NJ: Prentice-Hall, ch. 3, pp. 61-74, 1993.

[1] G. Kumar, and R. Banerjee, "Supply chain collaboration index: an instrument to measure the depth of collaboration", Benchmarking: An International Journal, vol. 21, no. 2, pp. 184-204, 2014.

[2] M. Barratt, "Understanding the meaning of collaboration in the supply chain", Supply Chain Management: An International Journal, vol. 9, no. 1, pp. 30-42, 2004.

[3] M. M. Wilhelm, "Managing coopetition through horizontal supply chain relations: Linking dyadic and network levels of analysis", Journal of Operations Management, vol. 29, no. 78, pp. 663-676, 2011.

[4] Z. Wu, and T. Y. Choi, "Supplier-supplier relationships in the buyer-supplier triad: Building theories from eight case studies", Journal of Operations Management, vol. 24, no. 1, pp. 27-52, 2005.

[5] Z. Wu, T. Y. Choi, and M. J. Rungtusanatham, "Suppliersupplier relationships in buyer-supplier-supplier triads: Implications for supplier performance", Journal of Operations Management, vol. 28, no. 2, pp. 115-123, 2010.

[6] T. Y. Choi, and Z. Wu, "Taking the leap from dyads to triads: Buyer-supplier relationships in supply networks", Journal of Purchasing and Supply Management, vol. 15 np. 4, pp. 263266, 2009. 
[7] A. Tuomela, and A. Salonen, "Network service organisation: a multiple pilot study", Facilities, vol. 23, no. 3/4, pp. 128141, 2005.

[8] R. K. Yin, Case Study Research: Design and Methods, Fifth Edition., SAGE Publications, Inc, Los Angeles, 2013.

[9] Z. Wu, T. Y. Choi, and M. J. Rungtusanatham, "Suppliersupplier relationships in buyer-supplier-supplier triads: Implications for supplier performance", Journal of Operations Management, vol. 28 no. 2, pp. 115-123, 2010.

[10] R. Sariola, and M. M. Martinsuo, "Framework for enhanced third-party relationships in project networks", International Journal of Managing Projects in Business, vol. 8, no. 3, pp. 457-477, 2015.

[11] M. Martinsuo, and R. Sariola, "Developing a supplier's third-party relationships and cooperation in project networks", International Journal of Managing Projects in Business, vol. 8, no. 1, pp. 74-91, 2015.

[12] J. Y. Murray, and F. Q. Fu, "Strategic guanxi orientation: How to manage distribution channels in China?", Journal of International Management, vol. 22, no. 1, pp. 1-16, 2016. 